\title{
Landscape Genetics of Mammals in American Ecosystems
}

\author{
Alejandro Flores-Manzanero ${ }^{1,2 *}$ and Ella Vázquez-Domínguez ${ }^{1}$ \\ ${ }^{1}$ Departamento de Ecología de la Biodiversidad, Instituto de Ecología, Universidad Nacional Autónoma de México, 3er Circuito \\ Exterior, Anexo Jardín Botánico, Ciudad Universitaria, CP. 04510. Ciudad de México, México. Email: floresmanzanero10@gmail. \\ com (AFM), evazquez@ecologia.unam.mx (EVD). \\ ${ }^{2}$ Posgrado en Ciencias Biológicas, Universidad Nacional Autónoma de México, Coyoacán CP. 04510. Ciudad de México, México. \\ * Corresponding author
}

Since the term was coined in 2003, landscape genetics (LG) is a field that integrates population genetics, landscape ecology, and spatial analytical techniques to quantify the effects of landscape on microevolutionary processes. Despite the growing interest in LG, there is little knowledge about the trends in LG research for America in general and regarding mammals in particular, as well as about which ecosystems are being most studied. Deserts represent nearly one-third of the Earth's surface and are characterized by high heterogeneity and species richness. However, they are underrepresented in the LG literature. Hence, we performed a thorough review of published scientific articles addressing LG of mammals in America, with emphasis on deserts. The objectives were to 1) determine the mammal groups that have been most studied; 2) establish the representation of desert ecosystems; 3 ) describe the research questions and analytical methods most frequently used; and 4) summarize the key landscape factors and environmental variables associated with genetic diversity and structure patterns of mammals in America. We conducted a comprehensive literature search of published articles between 2003 and 2019 in the Web of Science (http://apps. webofknowledge.com) based on search words specific to the revision subject. We verified and screened the articles recovered, and gathered basic information (species, authors, publication year), together with the research questions addressed and the genetic and statistical methods used. We recovered 36 publications on LG involving mammals in America; of these, only eight were conducted on desert ecosystems (Table 1). Rodentia was the most represented order in all American ecosystems $(n=20)$, while Artiodactyla $(n=4)$ was specifically represented in deserts. Of all studies, the most common research questions focused on estimating 'connectivity' $(n=14)$ and 'genetic structure' $(n=12)$, and the most frequent analytical methods were Mantel and partial Mantel tests. Dispersal capabilities and vegetation cover were the most important variables regarding the genetic structure of desert populations. Most studies evaluated connectivity with simple and partial Mantel tests, but the use of novel methodologies (i. e., genomics) was also identified. Ecological traits of species, particularly for rodents, and vegetation cover were the main factors related to genetic patterns in deserts. Notably, we identified that North America is the most studied region, while LG studies with mammals are scarce in Mexico and South America (one study encompassed North and Central America), as well as in desert ecosystems, hence the urgency to conduct studies in those regions and in deserts.

La genética del paisaje (GP) integra conceptos y herramientas de la genética de poblaciones, ecología del paisaje y estadística espacial, para cuantificar los efectos de la matriz del paisaje en los procesos microevolutivos. Los ecosistemas de desierto están caracterizados por una alta heterogeneidad y riqueza de especies; sin embargo, están poco representados en la literatura de GP. Los objetivos de la presente revisión fueron: 1) conocer los grupos de mamíferos más estudiados, 2) determinar la representatividad de los ecosistemas desérticos, 3) describir las preguntas más frecuentes y los métodos y análisis utilizados, 4) resumir los principales factores del paisaje y del ambiente asociados con la diversidad y estructura genética de los mamíferos de América. Realizamos una búsqueda exhaustiva de estudios publicados sobre GP con mamíferos en ecosistemas de América (2003-2019, en Web of Science). Recopilamos información de referencia (especies, autores, año de publicación), y preguntas de investigación, aproximaciones metodológicas y análisis estadístico-espaciales. Obtuvimos 36 publicaciones, ocho desarrolladas en ecosistemas desérticos (Tabla 1). El orden más representado en ecosistemas de América fue Rodentia ( $n=20)$ y en particular en desiertos fue Artiodactyla $(n=4)$. Del total de trabajos, las preguntas enfocadas a estimar 'conectividad' $(n=14)$ y'estructura' $(n=12)$ fueron las más estudiadas, y los análisis más utilizados se basaron en pruebas de Mantel (simple y parcial). La capacidad de dispersión y la presencia de vegetación fueron variables clave. Aunque predominó la evaluación de conectividad mediante análisis de correlación entre matrices de distancias y pruebas de Mantel, identificamos el uso de metodologías novedosas, como la construcción de redes genéticas y demográficas a partir de matrices de resistencia. Cabe resaltar que las variables ecológicas de las especies, en particular de roedores, y la cobertura vegetal fueron clave en desiertos. Finalmente, identificamos que Norteamérica es la región más estudiada, mientras que existen pocos trabajos de GP con mamíferos en México y Sudamérica (un trabajo abarcó Norteamérica y Centroamérica) y en ecosistemas desérticos, por lo que es urgente realizar estudios en dichas regiones y en desiertos.

Key words: connectivity; gene flow; genetic structure; Mexico; rodents; spatial analysis.

C 2019 Asociación Mexicana de Mastozoología, www.mastozoologiamexicana.org

\section{Introduction}

Genetic variation is considered to be the basic level of biological diversity (McNeely et al. 1990) and is essential for the adaptation and survival of individuals, the viability of populations, and the ability of species to adapt to environmental changes (Frankham et al. 2010). Particularly since 1970 , genetic variation started being regarded as a key ele- ment of conservation (Frankel 1974). On the other hand, the acknowledgment of the impact of human activities on the environment in the 1980s - mainly fragmentation and habitat loss - gave rise to landscape ecology as the discipline that investigates the interactions between spatial heterogeneity and ecological processes (Turner 2005). In 2003 , the conceptual and methodological development of 
both disciplines laid the foundations for the recognition of Landscape Genetics (LG) as a discipline that evaluates the impact of environmental heterogeneity and the landscape elements on the variation and genetic structure of individuals and populations (Manel et al. 2003). LG integrates the concepts and tools of population genetics, landscape ecology, and spatial statistics, to quantify the effects of the landscape matrix (composition, configuration, and quality) on microevolutionary processes such as gene flow, drift and selection, based on neutral or adaptive genetic variation (Manel et al. 2003; Holderegger and Wagner 2006; Storfer et al. 2007; Balkenhol et al. 2015).

The impact of LG in the scientific community has led to a marked increase in the number of publications related to the topic, from 3 to 60 articles per year, over 10 years (Storfer et al. 2010). A variety of analytical and methodological approaches have emerged, including the stages that a LG study should follow (Garrido-Garduño and Vázquez-Domínguez 2013; Hall and Beissinger 2014), the consideration of temporal and spatial scales (Anderson et al. 2010), the sampling design and selection of molecular markers (Landguth et al. 2012), statistical analyses (Balkenhol et al. 2009a), and certain limitations and perspectives of LG (Balkenhol et al. 2009b; Richardson et al. 2016). In this sense, Storfer et al. (2010) analyzed empirical studies published up to that date; from their results, five points stand out: 1 ) there is a taxonomic bias toward vertebrates; 2) most works have been conducted in America; 3 ) forests are the most studied habitats; 4) the topic most frequently addressed is the identification of barriers affecting gene flow; and 5) deserts are scarcely represented ecosystems, with $3 \%$ of LG studies. Other revisions also point out that vertebrates are the dominant taxonomic group in LG studies at the global level (Garrido-Garduño and Vázquez-Domínguez 2013; Dyer 2015); of these, mammals have prevailed (Montgelard et al. 2014). It should be noted that although America is the region most represented in LG studies, there is no information currently available identifying the main topics of research, analytical methods used, and environments studied from an LG perspective.

Deserts are one of the Earth's more widespread environments, occupying approximately one-third of the Earth's surface (Schimel 2010). The environmental characteristics of deserts, such as high temperatures and low rainfall, have favored a variety of microhabitats that, in addition to hosting a large number of taxonomic groups, many of them endemic, also confer temporal and spatial heterogeneity (Whitford 2002; WWF 2019). Temporal heterogeneity emerges from highly variable environmental conditions throughout the day, between seasons of the year, or between years (Polis 1991); for its part, spatial heterogeneity influences species composition, distribution, and abundance (Whitford 2002; Ludwig et al. 2005). Thus, heterogeneity renders deserts ideal systems for hypothesis testing within the LG framework (Challenger and Soberón 2008). For instance, in the Chihuahuan desert, vegetation tends to be distributed in small patches (Grünberger 2004), producing a heterogeneous matrix that allows evaluating structural and functional connectivity (Manel and Holderegger 2013).

It is worth stressing that in the current context of global climate change, it is predicted that change rates toward warmer and more arid environments will rise in deserts relative to other regions. This, coupled with the transformation and loss of natural habitats in desert ecosystems (Mittermeier et al. 2003; Zeng and Yoon 2009; WWF 2019), have supported that deserts be presently considered as vulnerable regions, particularly the deserts of North America (Bachelet et al. 2016; WWF 2019). Therefore, due to the overall scarce representation of deserts in the literature of landscape genetics (Storfer et al. 2010), we deem it essential to determine the state of the art of $L G$ research in American deserts. Its relevance lies in the fact that the persistence of species inhabiting desert ecosystems depends on the dispersal ability of individuals and the movement of genes within and between their populations across the landscape (Scribner et al. 2005; Reding et al. 2013).

Based on the above arguments, in the present work we conducted a review of the scientific literature aiming to 1) determine the most studied groups of mammals; 2) determine the representativeness of desert ecosystems; 3 ) describe the research questions most frequently addressed and the methods and analysis used; and 4) summarize the main factors of the landscape and the environment associated with genetic diversity and structure of the mammals of America.

\section{Materials and Methods}

Literature review. We surveyed articles about landscape genetics (LG) with mammals in ecosystems of America published between 2003 - when the term was first coined and May 2019. We used the Web of Science website (http:// apps.webofknowledge.com) based on different combinations of terms as keywords: 'landscape genetics', 'functional connectivity' and 'mammals'; 'landscape genetics', 'mammals' and 'desert'; 'landscape genetics', 'mammals', 'desert' and 'America'; 'functional connectivity', 'mammals' and 'desert'. This literature search method has proved to be efficient in different review works (e. g., Storfer et al. 2010; Dyer 2015; Rico 2019), which also allows a systematic and repeatable analysis, although it certainly may exclude some works.

Literature validation and analysis. We conducted a detailed revision of the works obtained to the last screen (revision of the title, abstract, and methods), aiming to eliminate duplicated works and confirm that studies matched the search criteria (mammals, America, and desert). We considered only works that reported empirical data and that strictly corresponded to genetic landscape analysis, i. e., including at least one landscape variable and evaluating its relationship with genetic patterns. We collected information on species, authors, year of publication, environments (considering the most represented environment in the study area according to each work), research ques- 
tions (classified by 'type'), and statistical-spatial LG analysis used. The research questions were classified according to six types: 'connectivity', 'structure', 'gene flow', 'comparative analysis', 'association analysis' and 'adaptation'.

\section{Results}

Taxonomy, geographic region, and diversity of deserts. The results obtained for each combination of terms and search screened were as follows: 'landscape genetics', 'functional connectivity' and 'mammals' ( $n=85$ works); 'landscape genetics', 'mammals' and 'desert' $(n=78)$; 'landscape genetics', 'mammals', 'desert' and 'America' $(n=38)$; 'functional connectivity','mammals' and 'desert' $(n=10)$. After a thorough validation of the literature (elimination of duplicates, inclusion of works with empirical data only involving the analysis of landscape variables), a total of 36 publications were obtained (Table 1). We identified six orders of mammals, of which Rodentia was the most represented taxon ( $n=20$; Table 1$)$. The main geographic region studied was North America $(n=25)$, mostly in the United States of America $(n=19)$. For South America $(n=10)$, we identified works conducted in Brazil $(n=3)$, Argentina $(n=6)$, and Uruguay $(n=1)$. We recorded one study that covered countries of North America (Mexico) and Central America (Belize, Costa Rica, Guatemala, and Honduras), which was counted separately. The environments involved included forests $(n=6)$, urban areas $(n=6)$, cropland $(n=4)$, mountains and rivers $(n=5)$, sand dunes $(n=5)$, and shrub steppe $(n=2)$, while desert ecosystems were addressed in eight studies.

Specifically for deserts, Artiodactyla was the order most represented $(n=4)$, although with a single species (the desert bighorn sheep Ovis canadensis nelsoni), followed by the orders Carnivora (Ursus americanus and Bassariscus astutus) and Rodentia (Dipodomys spectabilis and Dipodomys merriami), with two works each. The deserts of North America (Mojave, $n=3$; Chihuahuan, $\mathrm{n}=3$; Sonoran $n=2$ ) were the only arid environments where LG studies have been carried out (Table 1). No studies were found addressing the deserts of South America (Atacama and Patagonia). For Mexico, we found only three LG works, two in the tropical deciduous forest of Oaxaca and San Luis Potosí, and the other one the coast of Jalisco; only a single study was conducted in the desert (Chihuahuan; Table 1).

Research questions and statistical-spatial methods. The classification of the research questions addressed in all the publications reviewed (North America) revealed that those dealing with 'connectivity' and 'structure' were the most common ones ( $n=14$ and 12, respectively), followed by 'gene flow' $(n=7)$. The 'comparative', 'association' and 'adaptation' approaches were represented by one work each. To note, the 'association' and the 'adaptation' approaches were unique to desert environments (Table 1).

All studies analyzed genetic aspects that included assessment of deviations from the Hardy-Weinberg equilibrium and linkage disequilibrium, as well as genetic diversity measures by estimating allelic richness and observed and expected heterozygosity. Four works performed allocation and structure analyses to define genetic groups and to detect migrants (Figure 1).

Regarding spatial data handling and recording (landscape and environmental variables), all studies used a Geographic Information System (GIS) to represent the study area. In addition, five works estimated the Normalized Difference Vegetation Index (NDVI) to obtain vegetation cover data. A study selected sampling sites based on the method of environmental domains (Figure 1). In the remaining works, the landscape was characterized through a classification based on the literature reported for the area, or from repositories of specific environmental information.

In all the studies at least two analytical methods were used for assessing the genetics-landscape relationship. The methods most commonly utilized were the Mantel and partial Mantel tests, followed by linear regression models and their variants ( $n=14$; Figure 1$)$. Some works addressing 'connectivity' and 'gene flow' questions constructed resistance layers to quantify the effects of landscape through the estimation of effective distances based on least-cost path algorithms $(n=6)$, resistance distance (estimated based on circuits theory; $n=6)$, and both $(n=4)$. One work used species distribution models (SDM) for the construction of these resistance layers (Figure 1).

Landscape factors that determine the genetic structure and diversity. The results obtained for America show that the environmental and landscape characteristics, represented as effective distances, are the ones that best explained genetic structure and diversity patterns in most works (Figure $2 \mathrm{a}$ ), followed by geographic distance (i. e., with a pattern of isolation by distance). The main landscape variables

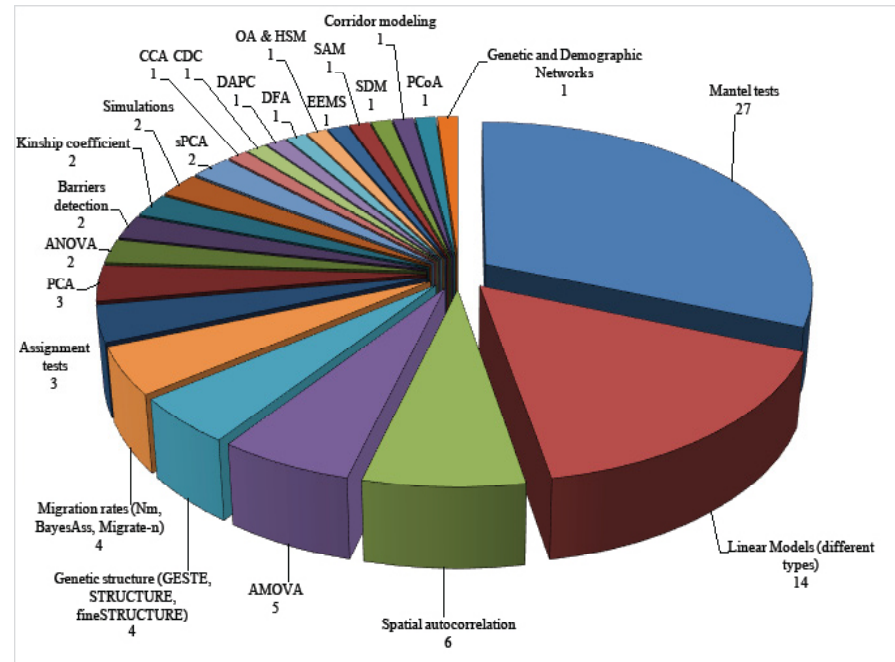

Figure 1. Analytical methods used in landscape genetics studies with mammals in North America. Numbers indicate the number of studies that used each method; all works used more than two methods. Abbreviations: ANOVA = Analysis of variance; AMO$\mathrm{VA}=$ Analysis of molecular variance; $\mathrm{CEC}=$ Canonical correspondence analysis; $C D C=$ Climatic domain classification; DAPC = Discriminant principal component analysis; DFA = Discriminant functional analysis; EEMS = Estimated effective migration rates; OA and HSM = Occupancy analyses and Habitat suitability model; PCA = Principal component analysis; $\mathrm{PCoA}=$ Principal coordinate analysis; $\mathrm{sPCA}=$ Spatial principal component analysis; $\mathrm{SAM}=$ Spatial autoregressive modeling; SDM = Species distribution models. 
included topography, vegetation cover (evaluated as NDVI and extent of available habitat in the landscape), rivers, and water bodies (Figure 2b). Additional relevant factors were anthropogenic constructions (highways and roads) and the ecological characteristics of species, such as dispersal capacity and population density. In particular in deserts, the factors most frequently associated with genetic structure and diversity were vegetation cover, dispersal, and anthropogenic constructions (Figure 2b).

a)

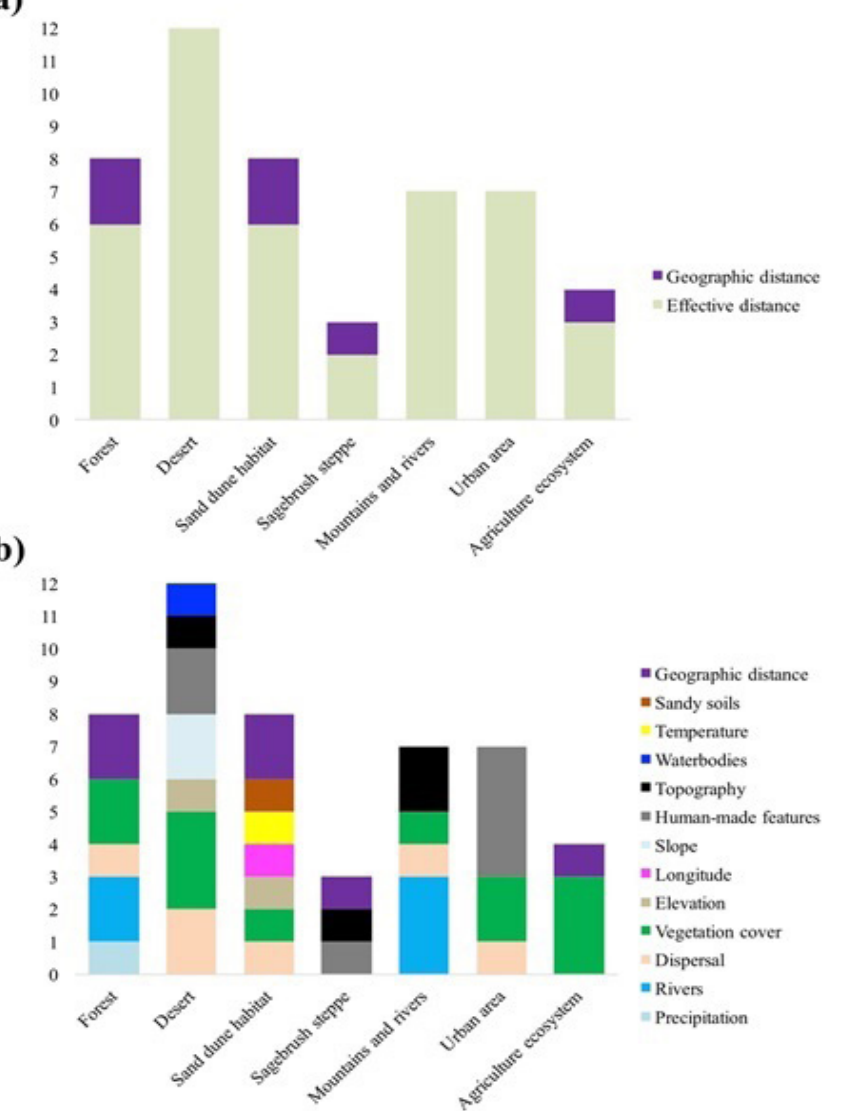

Figure 2. Factors that determine the genetic structure and diversity of mammals, expressed as accumulated frequencies in each of the environments analyzed. "Vegetation cover" includes the different approaches used to assess that characteristic (NDVI, habitat patches), as well as for "anthropogenic constructions" (roads, highways). a) Factors in terms of geographic and effective distance; b) environmental and landscape variables that constitute effective distances in each environment. "Longitude" refers to the geographic position in the coordinate system.

\section{Discussion}

Since the term was first coined to the steady construction of the theoretical, methodological, and analytical frameworks (Manel et al. 2003; Holderegger and Wagner 2006; Balkenhol et al. 2015), landscape genetics (LG) has been broadly accepted in the scientific community to address questions related to the effect of the environmental variables in the genetic structure and variation of natural populations (Storfer et al. 2010; Garrido-Garduño and Vázquez-Domínguez 2013; Dyer 2015). Mammals comprise 6,399 species worldwide (of the 6,495 recognized species, 96 have become extinct); of these, 697 are located in the Nearctic region, which covers North America (Burgin et al. 2018). Our results show that this region is the best represented in LG studies with mammals, covering a great diversity of ecosystems. A study that encompasses North America and Central America is worth mentioning (Wultsch et al. 2016), and could be considered as one of the first addressing LG for this region. In addition, we found scarce research efforts done (and published) on landscape genetics involving the mammals of Mexico and South America, as well as in desert ecosystems.

Rodents and carnivores, models in landscape genetics in North America. Rodentia is considered the largest order, with 2,409 species that account for approximately $44 \%$ of the diversity of mammals worldwide (Wilson et al. 2017). The characteristics of rodents, namely high species richness, small size (most species), limited dispersal capabilities, and diverse life stories, make them an ideal taxonomic group to address questions at the landscape scale, together with genetics and ecology. It is striking, however, that it was only recently that the qualities of this group were recognized within the context of landscape studies (Waits et al. 2015).

Studies involving rodents in America have been conducted mainly in areas with anthropogenic impact, including urban areas (Gardner-Santana et al. 2009; Chambers and Garant 2010; Mapelli et al. 2012; Munshi-South 2012; Marrotte et al. 2014; Anderson et al. 2015; Chiappero et al. 2016; Combs et al. 2018). On the other hand, we found only two works that were conducted with rodents in desert environments, specifically kangaroo rats in the Chihuahuan desert. In the first study, Cosentino et al. (2015) evaluated the population genetics of $D$. spectabilis from a spatial perspective, considering the configuration of the landscape matrix; they found that genetic differentiation patterns of its populations are determined by biological aspects of the species, specifically the dispersal capacity and population densities. In the second work, Flores-Manzanero et al. (2019) found higher gene flow in a population of $D$. merriami along areas with shrub vegetation, which in turn is associated with the construction of burrows and as a food source (seeds); accordingly, based on a LG approach these authors found a relationship between genetic patterns and ecological processes.

Carnivores were the second most represented order in landscape genetics studies in America, encompassing both medium-sized species such as the fisher (Martes pennanti; Hapeman etal. 2011) and the"cacomixtle" (ringtail, Bassariscus astutus; Lonsinger et al. 2015), as well as large species, including the gray wolf (Canis lupus; Cullingham et al. 2016), the black bear (Ursus americanus; Atwood et al. 2011; Draheim et al. 2018), and the jaguar (Panthera onca; Wultsch et al. 2016). Notably, carnivores are recognized as the most vulnerable to extinction group of mammals, due to their biological characteristics and anthropogenic impacts (Cardillo et al. 2004). The few studies identified in this review highlight the importance of conducting genetic landscape research to explore, among others, the effect of landscape elements (mountains, rivers) and anthropogenic features (habitat fragmentation) on the diversity and genetic structure of this group.

Evaluation of connectivity. Landscape genetics has focused primarily on terrestrial organisms (Storfer et al. 
Table 1. Summary of landscape genetics studies with mammals analyzed in this review.

\begin{tabular}{|c|c|c|c|c|c|c|c|}
\hline $\begin{array}{l}\text { ORDER/ } \\
\text { Species }\end{array}$ & $\mathbf{F}$ & Region & $\begin{array}{l}\text { Environment/ } \\
\text { landscape }\end{array}$ & Research question & $\begin{array}{l}\text { Type of ques- } \\
\text { tion }\end{array}$ & Statistical-spatial analysis & $\begin{array}{c}\text { Genetic structure and diversity } \\
\text { drivers }\end{array}$ \\
\hline \multicolumn{8}{|l|}{ DIDELPHIMORPHIA } \\
\hline Marmosops incanus & 1 & $\begin{array}{l}\text { Atlantic Plain, } \\
\text { Brazil }\end{array}$ & $\begin{array}{l}\text { Forests with dif- } \\
\text { ferent degrees of } \\
\text { fragmentation }\end{array}$ & $\begin{array}{l}\text { Comparative landscape ge- } \\
\text { netics Response of genetic } \\
\text { diversity to fragmentation }\end{array}$ & $\begin{array}{l}\text { Comparative } \\
\text { analysis }\end{array}$ & $\begin{array}{l}\text { ANOVA, regression models, } \\
\text { and Mantel tests }\end{array}$ & $\begin{array}{l}\text { Amount of available habitat across the } \\
\text { landscape (\% patch cover) }\end{array}$ \\
\hline
\end{tabular}

PRIMATES

Leontopithecus rosalia

Uniao Bio- $\quad$ Fragmented

logical Reserve, Atlantic forest Brazil
Evaluate the effect of the Gene flow

landscape in gene flow

Spatial autocorrelation, kin- The spatial configuration of vegetation ship indices, and generalized cover affects the dispersal of individulinear models

\section{LAGOMORPHA} $\begin{array}{ll}\text { Brachylagus idahoensis } 3 \quad \begin{array}{l}\text { Wyoming, Esta- Shrub steppe } \\ \text { dos Unidos }\end{array} & \end{array}$

$\begin{array}{llll}\text { Ochotona princeps } & 4 & \begin{array}{l}\text { Oregon, Esta- } \\ \text { dos Unidos }\end{array} & \begin{array}{l}\text { Mountains and } \\ \text { rivers }\end{array} \\ \text { Sylvilagus transitionalis } & 5 & \begin{array}{l}\text { Eastern United } \\ \text { States }\end{array} & \begin{array}{l}\text { Fragmented } \\ \text { habitat / Urban } \\ \text { zone }\end{array}\end{array}$

RODENTIA

Calomys venustus

6 Córdoba, Argentina

Farming areas with roads

Assess spatial and tempo- Structure ral genetic structures tial genetic structure pattern is due to isolation by distance or by barriers limit or facilitate gene flow
Evaluate whether the spa- Structure

Identify the factors that Geneflow

Assess connectivity Connectivity

Evaluate the environmen- Structure tal factors that shape population structure and those that promote the connectivity between populations

Assess the spatial genetic Structure structure

lagoons and

cropland
Ctenomys porteousi $9 \quad$ Buenos Aires, Cultivation and Argentina farming areas

Evaluate the effect of land- Connectivity scape configuration on genetic structure and connectivity. Migration rates

\begin{tabular}{|c|c|c|c|c|c|}
\hline Ctenomys rionegrensis & 10 & $\begin{array}{l}\text { Río Negro, } \\
\text { Uruguay }\end{array}$ & $\begin{array}{l}\text { Dune and river } \\
\text { systems }\end{array}$ & $\begin{array}{l}\text { Evaluate the geographic } \\
\text { factors that shape popula- } \\
\text { tion structure }\end{array}$ & Structure \\
\hline Ctenomys sp. & 11 & $\begin{array}{l}\text { Corrientes, } \\
\text { northeast } \\
\text { Argentina }\end{array}$ & $\begin{array}{l}\text { Flood-prone area } \\
\text { including la- } \\
\text { goons, marshes, } \\
\text { and cropland }\end{array}$ & $\begin{array}{l}\text { Evaluate the geographic } \\
\text { factors that shape popula- } \\
\text { tion structure }\end{array}$ & Structure \\
\hline * Dipodomys merriami & 12 & $\begin{array}{l}\text { Mapimí, Du- } \\
\text { rango, México }\end{array}$ & $\begin{array}{l}\text { Chihuahuan } \\
\text { desert }\end{array}$ & $\begin{array}{l}\text { Evaluate the landscape fea- } \\
\text { tures that limit or facilitate } \\
\text { gene flow }\end{array}$ & Gene flow \\
\hline${ }^{*}$ Dipodomys spectabilis & 13 & $\begin{array}{l}\text { Nuevo México, } \\
\text { Estados Unidos }\end{array}$ & $\begin{array}{l}\text { Chihuahuan } \\
\text { desert }\end{array}$ & $\begin{array}{l}\text { Evaluate the presence of } \\
\text { a founder effect on re- } \\
\text { colonized sites based on } \\
\text { genetic diversity, size, and } \\
\text { connectivity between sites }\end{array}$ & Connectivity \\
\hline $\begin{array}{l}\text { Hydrochoerus hydro- } \\
\text { chaeris }\end{array}$ & 14 & $\begin{array}{l}\text { Basins of } \\
\text { Venezuela, } \\
\text { Paraguay, and } \\
\text { Argentina }\end{array}$ & River systems & $\begin{array}{l}\text { Assess spatial genetic } \\
\text { structure }\end{array}$ & Structure \\
\hline Lagidium viscacia & 15 & $\begin{array}{l}\text { Neuquén, } \\
\text { Argentina }\end{array}$ & $\begin{array}{l}\text { Steppe and } \\
\text { mountains }\end{array}$ & $\begin{array}{l}\text { Evaluate functional con- } \\
\text { nectivity }\end{array}$ & Connectivity \\
\hline
\end{tabular}

Analysis of isolation by dis- Geographic distance, with a road as a tance at individual and popu- likely barrier lation levels

Genetic distance, resistance Topographic complexity is the main distances, simple and partial driver of gene flow Mantel tests, simulations

Resistance matrix, partial Linear anthropogenic constructions Mantel tests, Least-cost path and shrub habitats (effective distance) and mixed-effect models

Spatial autocorrelation analy- Geographic distance only sis, Mantel and partial Mantel tests. Correlation between genetic and "geographic" distances

AMOVA, simple and partial Plant cover (NDVI) and Longitude proMantel tests, spatial principal mote gene flow between populations component analysis (sPCA), generalized linear models

Correlation between genetic Geographic distance, probably due to and geographic distances, the species limited dispersal Mantel tests, assignment analysis, AMOVA

Connectivity between habitat Amount of available habitat across patches. Correlation between the landscape and distance between genetic and geographic dis- good-quality patches.

tances. Mantel and partial

Mantel tests, generalized linear model.

Mixed generalized models Elevation

Analysis of structure (GESTE), The presence of well-drained sandy species distribution models soils and temperature are the drivers and linear models for the distribution and differentiation of populations

Linear mixed-effect models Effective distance (NDVI) best explains from resistance surfaces and gene flow patterns, which is favored in model evaluation using AIC areas with vegetation cover

Correlation between genetic Dispersal characteristics associated and geographic distances. with population density Mantel test, mixed generalized models

AMOVA. Principal Coordinate Rivers determine the structure pattern Analysis and Canonical Correspondence. Resistance distance

Correlation between genetic, Functional connectivity is influenced geographic and cost distanc- by landscape geology es. Mantel tests 


$\begin{array}{llll}\text { Liomys pictus } & \text { Western Mexico } & \begin{array}{l}\text { Tropical decidu- } \\ \text { ous forest }\end{array} & \begin{array}{l}\text { Evaluate the effect of land- Gene flow } \\ \text { scape elements on genetic } \\ \text { structure and gene flow. }\end{array}\end{array}$

\begin{tabular}{|c|c|c|c|c|c|}
\hline Microtus californicus & 17 & $\begin{array}{l}\text { Jasper Ridge } \\
\text { Reserve, Cali- } \\
\text { fornia, United } \\
\text { States }\end{array}$ & $\begin{array}{l}\text { Grasslands and } \\
\text { oak forest }\end{array}$ & Evaluate gene flow & Gene flow \\
\hline Ondatra zibethicus & 18 & $\begin{array}{l}\text { Sudbury, On- } \\
\text { tario, Canada }\end{array}$ & Watersheds & $\begin{array}{l}\text { Evaluate the effect of land- } \\
\text { scape characteristics on } \\
\text { structure and connectivity. }\end{array}$ & Connectivity \\
\hline Peromyscus leucopus & 19 & $\begin{array}{l}\text { New York, } \\
\text { United States }\end{array}$ & Urban zone & $\begin{array}{l}\text { Evaluate the landscape } \\
\text { characteristics that fos- } \\
\text { ter connectivity between } \\
\text { populations in an urban } \\
\text { environment }\end{array}$ & Connectivity \\
\hline P. leucopus & 20 & $\begin{array}{l}\text { Montérégie, } \\
\text { Quebec, } \\
\text { Canada }\end{array}$ & $\begin{array}{l}\text { Farming land } \\
\text { with rivers and } \\
\text { roads }\end{array}$ & $\begin{array}{l}\text { Evaluate the effect of the } \\
\text { landscape characteristics } \\
\text { on genetic structure and } \\
\text { connectivity. }\end{array}$ & Connectivity \\
\hline
\end{tabular}

$\begin{array}{lclll}\text { Rattus norvegicus } 21 \quad \begin{array}{l}\text { Baltimore, Urban zone } \\ \text { Maryland, } \\ \text { United States }\end{array} & \begin{array}{l}\text { Characterize the genetic Gene flow } \\ \text { structure and evaluate } \\ \text { gene flow }\end{array} \\ \text { R.norvegicus } & \begin{array}{l}\text { New York, Urban zone } \\ \text { United States }\end{array} & \begin{array}{l}\text { Explore spatial genetic Structure } \\ \text { structure patterns }\end{array}\end{array}$

Tamias striatus

23

south Quebec and Ontario, Canada

Forested areas, $\begin{array}{ll}\text { rivers, and urban factors that shape popula- } \\ \text { areas } & \text { tion structure; sex-biased }\end{array}$ dispersal

T. striatus 24

Indiana, United States

Patches of forest and farmland

Evaluate functional con- Connectivity nectivity

Assess connectivity in Connectivity among rivers using three environmental distances. Migration rate

\section{CARNIVORA}

*Bassariscus astutus

Canis lupus

Panthera onca
Olympic Peninsula, Washforest

\begin{tabular}{|c|c|c|}
\hline 26 & $\begin{array}{l}\text { Southwest } \\
\text { United States }\end{array}$ & $\begin{array}{l}\text { Desert and } \\
\text { mountains } \\
\text { Chihuahuan }\end{array}$ \\
\hline 27 & Rocky Moun- & Mountains \\
\hline
\end{tabular}
tains, Canada
Assess connectivity pat- Connectivity terns associated with genetic structure: IBD, IBR, IBE

Evaluate gene flow be- Geneflow tween herds considering the landscape characteristics

28

Northeast United States

Moun

In Mexico: Sierra Mixe, Oaxaca, and Sierra de Abra-Tanchipa, San Luis Potosí. In Central America: Belize, Costa Rica, Guatemala, Honduras
Environmental domains. Womb- Effective distance, precipitation and soft, Barrier. Correlation between streams

genetic and geographic distanc-

es. Effective distance: Least-cost

path and circuit theory. Mantel

and partial Mantel tests

Principal component analysis, Only geographic distance, due to the Mantel tests ecological characteristics.

Spatial autocorrelation by sex. Roads and anthropogenic elements Assignment analysis. Corre- seem to facilitate the movement of lation between genetic, lin- organisms

ear and resistance distances (least-cost path). PATHMATRIX.

Partial Mantel tests

Migration rates ( $\mathrm{Nm}$, BayesAss Effective distance (based on vegetaand Migrate-n). Linear, effec- tion cover)

tive (least-cost) and resistance

distances. Mantel and partial

Mantel tests

Correlation between genetic Forest fragments facilitate the moveand ecological distances. ment of individuals

Mantel tests. Multiple regres-

sion analysis between ecolog-

ical and linear distances. Con-

nectivity between patches

with resistance distance

Genetic distance, kinship rela- Habitat fragmentation (urban area); the tions, and Mantel tests ecology of organisms contribute to homogenize diversity and genetic structure

Spatial autocorrelation, Man- Closely related individuals and ecologitel tests, PCA, SPCA, estimated cal characteristics of the species effective migration surfaces

(EEMS), population structure (fineSTRUCTURE)

Correlation between genetic The river is the main barrier, as well as and geographic distances sex-biased dispersal (males)

Mantel test. Identification of

barriers (Barrier). AMOVA

Assignment analysis. Corre- Vegetation cover promotes gene flow lation between genetic and geographic distances. Mantel test. Coverage distances. Regression models

Spatial autocorrelation analy- Effective distance (topographic and risis. Mantel test. Estimation of parian landscape features) and limited migration rates species dispersal

Partial Mantel tests. Discrimi- Environmental characteristics: elevanant function analysis. ANO- tion, slope, and vegetation type (IBEVAs effective distance)

Regression between genetic Effective distance (based on vegetaand geographic distances (re- tion cover)

sistance model and coverage

distance). Multiple regressions

of distance matrices. Partial Mantel tests

Correlation between genetic, Orographic and hydrological charac geographic and barrier distanc- teristics (i.e. river and great lakes)

es. Mantel and partial Mantel

tests. Recent migration rates

Analysis of population struc- Geographic distance, probably due to ture, PCA, AMOVA, spatial habitat fragmentation autocorrelation, and Mantel tests. 


$\begin{array}{lclll}* \text { *Usus americanus } & 30 & \begin{array}{l}\text { Arizona, United } \\ \text { States }\end{array} & \begin{array}{l}\text { Mountains and } \\ \text { Sonoran and } \\ \text { Chihuahuan } \\ \text { deserts }\end{array} & \begin{array}{l}\text { Evaluate connectivity and Connectivity } \\ \text { identify potential corridors }\end{array} \\ \text { U.americanus } & 31 & \begin{array}{l}\text { Michigan, } \\ \text { United States }\end{array} & \begin{array}{l}\text { Cultivation and } \\ \text { farming areas }\end{array} & \begin{array}{l}\text { Evaluate the effect of land- Structure } \\ \text { scape changes on spatial } \\ \text { genetic structure through } \\ \text { time. }\end{array}\end{array}$

ARTIODACTYLA

Odocoileus hemionus

Southern Cali-

States

\begin{tabular}{|c|c|c|c|}
\hline $\begin{array}{l}\text { * Ovis canadensis } \\
\text { nelsoni }\end{array}$ & 33 & $\begin{array}{l}\text { Southeast Cali- } \\
\text { fornia, United } \\
\text { States }\end{array}$ & $\begin{array}{l}\text { Mojave and } \\
\text { Sonoran } \\
\text { deserts }\end{array}$ \\
\hline * O. c. nelsoni & 34 & $\begin{array}{l}\text { Southwest } \\
\text { United States }\end{array}$ & $\begin{array}{l}\text { Mojave } \\
\text { desert }\end{array}$ \\
\hline * O. c. nelsoni & 35 & $\begin{array}{l}\text { Southwest } \\
\text { United States }\end{array}$ & $\begin{array}{l}\text { Mojave } \\
\text { desert }\end{array}$ \\
\hline
\end{tabular}

Assess connectivity be- Connectivity

tween populations, con-

sidering the effect of slope

and anthropogenic pres-

ence

Combine connectivity by Connectivity

landscape resistance mod-

els and network theory to

prioritize patches or cor-

ridors for conservation

purposes

Implementing NDVI as a Association predictor of food quality

and genetic diversity
Analysis of occupation based Fragmentation/barrier associated with on landscape characteristics the construction of the border wall (e.g. coverage). Habitat availability model. Resistance layers and corridor modeling

Simple and partial Mantel Vegetation cover showed a better retests, resistance distances, lationship with genetic distance, while FRAGSTATS, autoregressive variables associated with environmenspatial model, selection of tal heterogeneity better predicted the models based on AIC genetic change over time
Genetic structure (STRUC- Highways restrain the connectivity beTURE and DAPC), genetic dis- tween populations and individuals tances between individuals, habitat accumulated cost distance (HAC), least-cost path, generalized linear mixed-effect models

Migration rates. Correlation Effective distance (based on topograbetween genetic and geo- phy) graphic distances. Least-cost path. Partial Mantel test

Effective resistance distance Effective distance (based on maximum (least-cost path). Partial Man- dispersal)

tel tests. Genetic and demo-

graphic network models. Cor-

relations

$\begin{array}{llll}* \text { O. c.nelsoni } 36 & \begin{array}{l}\text { Southwest } \\ \text { United States }\end{array} & \begin{array}{l}\text { Mojave } \\ \text { desert }\end{array} & \begin{array}{l}\text { Explore the effects of land- Adaptation } \\ \text { scape on the spacing of } \\ \text { adaptive genetic variation }\end{array}\end{array}$

\author{
Linear quadratic regression Patches with high NDVI values \\ models to measure the as- \\ sociation between NDVI and \\ genetic diversity (response \\ variables). Connectivity met- \\ rics as an additional predictor \\ variable
}

Linear regression models from Effective distance (terrain slope, waresistance (least-cost) surfaces ter bodies, and roads determine gene and simulations flow)

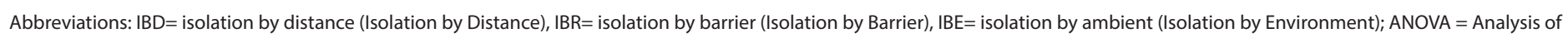
variance; $\mathrm{AMOVA}=$ analysis of molecular variance; $\mathrm{PCA}=$ Principal component analysis.

* = study explicitly conducted in a desert.

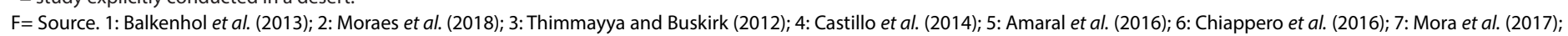

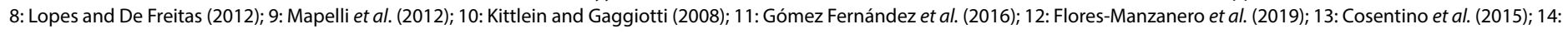

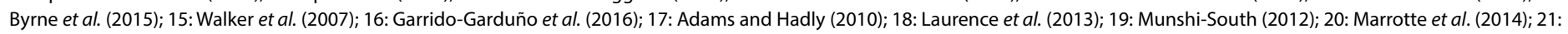

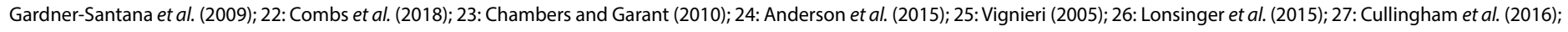

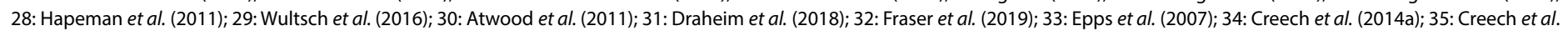
(2014b); 36: Creech et al. (2017)
\end{abstract}

2010; Garrido-Garduño and Vázquez-Domínguez 2013; Dyer 2015), where the development of tools, like geographic information systems (GIS), has allowed a more real representation of terrestrial landscapes (Waits et al. 2015). In this review, we found that one of the LG questions most frequently addressed globally (America) was the connectivity between populations, and all studies evaluating this topic used GISs to represent the landscape. These studies also used different analytical methods to relate the landscape with the genetic structure of populations, including the correlation between genetic distances and different geographic distances, since just the linear (Euclidean) distance does not represent the true distance between populations (Vignieri 2005). The so-called effective distance or functional distance represent ecological measures of distance commonly used in LG studies, the most used being the least-cost path and the resistance distance (Storfer et al. 2007; McRae et al. 2008). Also, the Mantel and partial Mantel tests were the approaches most frequently used to evaluate the correlation between these distances. Although the use of Mantel tests has been questioned (see Guillot and Rousset 2013), they are considered appropriate methods when setting hypotheses that explicitly involve distance (Legendre and Fortin 2010; Legendre et al. 2015), while also favoured as models that are easy to interpret and serve as starting points for the parameterization of resistance matrices (Storfer et al. 2010). For example, Munshi-South (2012) evaluated the connectivity between populations of the whitefooted mouse (Peromyscus leucopus) in an urban area using estimates of migration rates and correlating these with cost and resistance distances, supported on the resolving power of GISs and Mantel and partial Mantel tests. Also, in an environment with anthropogenic impact, Amaral et al. (2016) assessed the connectivity between populations of the gray rabbit (Sylvilagus transitionalis) from cost and resistance distances, which were optimized using correlations through 
partial Mantel tests. Likewise, Draheim et al. (2018) implemented simple and partial Mantel tests to correlate genetic distances between paired individuals with geographic (linear) and resistance distances, to evaluate whether changes in the landscape over time influenced the spatial genetic structure of the black bear (Ursus americanus).

An aspect worth mentioning is the development of additional methods to assess connectivity in terms of the relationship between effective and genetic distances, like the generalized linear models, which prevailed in studies with rodents (Kittlein and Gaggiotti 2008; Mapelli et al. 2012; Marrotte et al. 2014; Cosentino et al. 2015). We should also highlight the use of species distribution models for the construction of connectivity hypotheses in landscape genetics, as these combine presence data (localities where the species has been recorded) and climate data associated with that locality, also considering vegetation cover, topography, and other environmental variables (Rolland et al. 2015). For instance, Gómez Fernández et al. (2016) modeled the distribution of the tuco-tuco (Ctenomys sp.), taking into consideration the environmental variables available for the flooded area where it thrives, which allowed determining that permeable sandy soils and temperature are the factors significantly associated with its population genetic structure. Notably, the use of species distribution models in LG studies is restrained by the geographic scale, since most of the variables used for constructing these models are available at large scales (for example, the WorldClim layers have $1 \mathrm{~km}^{2}$ resolution; Hijmans et al. 2005) and, therefore, their use is restricted to considering large areas.

Finally, we highlight the construction of genetic and demographic networks from resistance matrices. As an example, Creech et al. (2014a) combined resistance models with the network theory and evaluated their correlation with partial Mantel tests to identify patches and corridors that facilitate the connectivity between populations of the bighorn sheep (Ovis canadensis nelsoni). Thus, this analytical approach can be useful for identifying corridors, particularly in conservation studies.

Not surprisingly, connectivity is one of the topics most commonly addressed in landscape genetics, particularly under the current context of global changes that currently affect (and will continue to affect) the habitat of multiple species (Manel and Holderegger 2013).

Genomics, gene flow, and local adaptation. The work in landscape genetics has been based largely on the use of neutral genetic markers, such as microsatellite loci. However, given the accelerated transformation of natural environments, it is increasingly important to be able to assess the patterns derived from adaptive genetic variation, especially because there lies the potential of species to respond to these changes (Manel et al. 2003; Balkenhol et al. 2015). In this sense, the use of molecular markers such as SNPs (Single Nucleotide Polymorphisms) has made it possible to multiply the number of loci by the thousands, increasing the statistical power of landscape genetic analyses (Combs et al. 2018). Also, since these markers are distributed throughout the genome, it is feasible to identify those that correspond to genes subject to selection. Therefore, the movement of these variants through gene flow between individuals and populations is largely determined by the characteristics of the landscape (Creech et al. 2017). In this review we found that Combs et al. (2018) used thousands of markers $(61,400 \mathrm{SNPs})$ to explore the patterns of spatial genetic structure of the Norway rat (Rattus norvegicus) in New York. The authors proved the existence of genetic structure at a fine spatial scale, attributed to the elements of the urban matrix and the ecological characteristics of the species. Also, these authors mention that previous studies, with the same species and using microsatellites, did not detect genetic structure patterns, highlighting the resolving power of SNPs in LG studies. On the other hand, Creech et al. (2017) explored the effects of landscape elements in gene flow from the optimization of resistance models, using simulations in populations of the bighorn sheep (a species that inhabits desert environments). Their results from simulations based on loci subject to selection show a higher gene flow of variants (loci) with adaptive potential in habitats with a continuous distribution of vegetation cover, among other variables. The above is particularly relevant in the context of the vulnerability of desert ecosystems (Bachelet et al. 2016; WWF 2019) and, therefore, the species that inhabit these systems, because their persistance will depend on the movement of genes with adaptive potential through an environment with scarce vegetation.

Remote sensing. One of the most powerful tools that has contributed to the generation of spatially explicit predictive variables is the information obtained from satellites, $i$. e., remote sensing (He et al. 2015). With our revision we evidence that one of the most innovative aspects in landscape genetics studies is the use of remote sensing information to achieve a more realistic interpretation of the landscape studied. For instance, Mapelli et al. (2012) used Landsat ETM+ sensor images to identify habitat patches in their study area and extract reflectance values of each, which were used to generate predictive variables. Thereby, the distance between good-quality patches was determined to be the most significant factor associated with the genetic structure patterns in Ctenomys porteousi. An additional sensor used to obtain satellite images is LiDAR, which has a higher resolution than Landsat, particularly for retrieving information on vegetation (Lefsky et al. 2002). Thus, Amaral et al. (2016) used LiDAR images to generate resistance layers used to assess the connectivity across populations of the rabbit Sylvilagus transitionalis and showed that patches of shrub vegetation facilitate gene flow in this species. As to its use in desert environments, Creech et al. (2014b) used MODIS (Moderate Resolution Imaging Spectroradiometer) images to extract reflectance values for vegetation and to estimate the NDVI, which is significantly associated with genetic diversity values in Ovis canadensis nelsoni; that is, 
vegetation determines the functional connectivity in this species. Flores-Manzanero et al. (2019), using Landsat 8 images, also calculated the NDVI for detecting the vegetation cover at a fine spatial scale, which produced various resistance models; the NDVI turned out to be the best predictor of gene flow for Dipodomys merriami. This strongly supports the conclusion that remote sensing is an excellent tool for landscape genetics studies, particularly in deserts, where the fine-scale definition of the various aspects of the landscape may be a complex issue.

Factors that determine genetic structure and diversity in mammals. The theoretical and methodological framework of population genetics is useful for inferring the patterns that govern the genetic structure and diversity of populations (Freeman and Herron 2002). Landscape genetics allows testing these inferences through hypothesis in a spatially explicit context (Manel et al. 2003; Holderegger and Wagner 2006; Balkenhol et al. 2015). The studies reviewed tested different environmental and landscape variables associated with genetic patterns in mammals. Geographic distance was the most significant variable and was best represented in rodents (California vole, Microtus californicus, Adams and Hadly 2010; pygmy rabbit, Brachylagus idahoensis, Thimmayya and Buskirk 2012; tuco tuco, Ctenomys lami, Lopes and De Freitas 2012; Córdoba vesper mouse, Calomys venustus, Chiappero et al. 2016), and in one carnivore (Panthera onca, Wultsch et al. 2016). Although in most studies anthropogenic impacts (fragmentation associated with agricultural land or roads) and low dispersal ability of species were identified as the drivers of the genetic patterns, we emphasize the importance of considering the greatest amount of environmental or ecological variables possible.

Also, most studies evaluated the effective distance from variables like topography (Vignieri 2005; Epps et al. 2007), vegetation cover (Munshi-South 2012; Lonsinger et al. 2015; Cullingham et al. 2016), precipitation and water bodies (Chambers and Garant 2010; Hapeman et al. 2011; Garrido-Garduño et al. 2016), available habitat, extent of fragmentation (Mapelli et al. 2012; Balkenhol et al. 2013), and anthropogenic impact (Gardner-Santana et al. 2009; Atwood et al. 2011; Amaral et al. 2016). Interestingly, some studies identify the ecological characteristics of species, in addition to environmental variables,as those that govern genetic diversity and structure patterns, particularly dispersal. For example, Chambers and Garant (2010) showed in the eastern chipmunk Tamias striatus that male-biased dispersal produces the structure pattern. Dispersal capability was also key in deserts, particularly for small mammals like Dipodomys spectabilis, since by incorporating population density data allowed detection of patterns that otherwise could have beeb attributed to geographic distance alone (Cosentino et al. 2015). In addition, one of the most significant factors for the bighorn sheep was maximum dispersal distance (i.e., effective distance), in addition to topography and food quality (estimated from the NDVl; Epps et al. 2007; Creech et al. 2014b). In fact, considering the maximum dispersal distance significantly improved the connectivity models, thus highlighting the importance of considering this little-used variable (Creech et al. 2014a). Finally, for large carnivores such as Ursus americanus, anthropogenic impact is the most important factor; for instance, the wall along the Mexico and USA border, is a significant barrier to dispersal and gene flow across populations (Atwood et al. 2011). Among medium-sized mammals like cacomixtle (Bassariscus astutus), the environment is the primary driver represented by the combination of vegetation type, slope, and elevation (Lonsinger et al. 2015).

North America... without Mexico? North America is the geographic region with the largest number of landscape genetics studies (Storfer et al. 2010). However, when Mexico was considered separately in our review, our analysis revealed the scarcity of studies despite its status as a megadiverse country that hosts a great variety of ecosystems (Mittermeier et al. 1997) and a high mammal richness, amounting to 496 species (Ramírez-Pulido et al. 2014). Although studies about genetics of the mammals of Mexico have been previously evaluated (Vázquez-Domínguez and Vega 2006), such assessment has not been done for landscape genetics. In this regard, it is important to mention that Rico (2019) recently published a review of landscape genetics studies conducted in Mexico to 2017, including 20 studies, with plants as the most studied taxonomic group (65\%), while only two studies focused on mammals. This finding is consistent with our results, since we identified three studies for Mexico, two on rodents; of these, only one was conducted in a desert area. Garrido-Garduño et al. (2016) evaluated the effect of the landscape elements on the genetic structure and gene flow of Liomys pictus in a tropical deciduous forest, while Flores-Manzanero et al. (2019) determined the landscape features that influence gene flow of Dipodomys merriami in a region of the Chihuahuan desert. In Mexico, the tropical deciduous forest occupies $11.26 \%$ of the national territory, mainly along the Pacific coast, while deserts represent $40 \%$ of the territory, distributed to the north and northwest (Challenger and Soberón 2008). Both ecosystems contain high levels of biodiversity and endemisms, particularly of animals (CONANP 2006; Ceballos et al. 2010); this, together with spatial and temporal heterogeneity, makes them suitable systems for hypothesis testing in a landscape genetics context.

Prospects for landscape genetics studies: the case of Mexico. From our review outlined here, we can assert that it is imperative in Mexico to conduct research addressing the effects of landscape and the environment on the distribution of genetic variation and structure of wild populations, through a spatially explicit approach. However, since rodents were the order of mammals most represented in this review, highlighting the studies conducted in Mexico, we believe landscape genetics studies with rodents will likely increase in the near future. This is based on the diversity of studies conducted with rodents in different environments in Mexico focused on aspects of genetic structure 
and diversity (Vega et al. 2007; Castañeda-Rico et al. 2011; Espindola et al. 2014), taxonomy and systematics (Arellano et al. 2006; Álvarez-Castañeda et al. 2009; Fernández et al. 2012), phylogeography (Espinoza-Medinilla et al. 2006; Gutiérrez-García and Vázquez-Domínguez 2012; ÁlvarezCastañeda and Murphy 2014), diversification and speciation (Castañeda-Rico et al. 2013; Pérez-Consuegra and Vázquez-Domínguez 2015), and even the development of molecular markers (Munguía-Vega et al. 2007; VázquezDomínguez and Espindola 2013), to mention a few. In addition, the development of environmental and climatic layers with better resolution for Mexico (Téllez-Valdés et al. 2010; Cuervo-Robayo et al. 2014) will be key for the development of these studies in the country, in combination with remote sensing data that are currently freely accessible (Landsat 8; http://landsat.usgs.gov/). Finally, deserts cover a large part of the national territory (ca. 70 million hectares; Challenger and Soberón 2008) and in some cases, as in the Chihuahuan desert, vegetation is patchily distributed (Grünberger 2004). It is worth highlighting that, although deserts can be thought of as relatively homogeneous systems, in reality the spatial distribution of the elements of the desert landscape renders a heterogeneous matrix that allows evaluating the structural and functional connectivity (Manel and Holderegger 2013), making deserts ideal ecosystems to conduct landscape genetics studies.

Some of the most significant advances for the study of landscape genetics in Mexico and elsewhere are worth mentioning, including the use of remote sensing data and species distribution models, which yield a better representation of the landscape and help to set hypotheses considering structure and connectivity within a spatially explicit context. The use of genomic tools (markers, bioinformatics methods, and analyses) and adaptive approaches will allow addressing questions not only regarding the effect of the landscape on genetic patterns but also about how individuals respond in terms of adaptation and selection.

\section{Acknowledgments}

We are grateful to C. López-González for the observations and comments on a preliminary draft of this manuscript, as well as to L. León-Paniagua and J. Golubov for their interest and discussions in the development of this research project. María Elena Sànchez-Salazar translated the manuscript into English. A. Flores-Manzanero thanks the Ph.D. Program (Programa de Doctorado en Ciencias Biológicas de la Universidad Nacional Autónoma de México) and CONACyT (CVU 440854/fellow 271066) for the economic support provided during the post-graduate studies. E. Vázquez-Domínguez received support from Dirección General de Asuntos del Personal Académico (Papiit IN201716) at UNAM.

\section{Literature cited}

Adams, R. I., And E. A. Hadly. 2010. High levels of gene flow in the California vole (Microtus californicus) are consistent across spatial scales. Western North American Naturalist 70:296-311.
Álvarez-Castañeda, S. T., And R. W. Murphy. 2014. The endemic insular and peninsular species Chaetodipus spinatus (Mammalia, Heteromyidae) breaks patterns for Baja California. PLoS ONE 9: e116146.

Álvarez-Castañeda, S.T., W.Z., JR. Lidicker, And E. Ríos. 2009. Revision of the Dipodomys merriami complex in the Baja California Peninsula, Mexico. Journal of Mammalogy 90:992-1008.

Amaral, K. E., M. Palace, K. M. O'Brien, L. E. Fenderson, and A. I. KovaCH. 2016. Anthropogenic habitats facilitate dispersal of an early successional obligate: implications for restoration of an endangered ecosystem. PLOS ONE DOI:10.1371/journal. pone.0148842.

Anderson, S. J., E. M. Kierepka, R. K. SWihart, E. K. Latch, and O. RHODES. 2015. Assessing the Permeability of Landscape Features to Animal Movement: Using Genetic Structure to Infer Functional Connectivity. PLOS ONE 10:e0117500. doi:10.1371/journal.pone.0117500.

Anderson, C. D., B. K. Epperson, M-J. Fortin, R. Holderegger, P. M. A. James, M. S. RosenberG, K. T. SCribner, and S. Spear. 2010. Considering spatial and temporal scale in landscape-genetic studies of gene flow. Molecular Ecology 19:3565-3575.

Arellano, E., D. S. Rogers, and F. X. González-Cózatl. 2006. Sistemática molecular del género Reithrodontomys (Rodentia: Muridae). Pp. 27-35 in Genética y mamíferos mexicanos: presente y futuro (Vázquez-Domínguez, E., and D. J. Hafner, eds.). New Mexico Museum of Natural History and Science. Albuquerque, U.S.A.

Atwood, T. C., J. K. Young, J. P. Beckmann, S. W. Breck, J. Fike, O. E., JR. RHODES, AND K. D. BRISTOW. 2011. Modeling connectivity of black bears in a desert sky island archipielago. Biological Conservation 144:2851-2862.

Bachelet, D., K. Ferschweiler, T. Sheehan, and J. Strittholt. 2016. Climate change effects on southern California deserts. Journal of Arid Environments 127:17-29.

Balkenhol, N., L. P. Waits, and R. J. Dezzani. 2009a. Statistical approaches in landscape genetics: an evaluation of methods for linking landscape and genetic data. Ecography 3:818-830. Balkenhol, N., S. A. Cushman, A. Storfer, and L. P. Waits. 2015. Introduction to Landscape Genetics - Concepts, Methods, Applications. Pp. 1-7 in Landscape Genetics: Concepts, Methods, Applications (Balkenhol, N., S. A. Cushman, A. T. Storfer, and L. P. Waits, eds.). John Wiley \& Sons, Ltd. The Atrium, Chichester, U.K.

Balkenhol, N., R. Pardini, C. Cornelius, F. Fernandes, and S. Sommer. 2013. Landscape-level comparison of genetic diversity and differentiation in a small mammal inhabiting different fragmented landscapes of the Brazilian Atlantic Forest. Conservation Genetics 14:355-367.

Balkenhol, N., F. Gugerl, S. A. Cushman, L. P. Waits, A. Coulon, J. W. Arntzen, R. HolderegGer, H. H. Wagner, and Participants of the LandsCape Genetics Research Agenda Workshop 2007 World Congress. 2009b. Identifying future research needs in landscape genetics: where to from here? Landscape Ecology 24:455-463.

Burgin, C. J., J. P. Colella, P. L. Kahn, and N. S. Upham. 2018. How many species of mammals are there? Journal of Mammalogy 99:1-14.

Byrne, M. S., R. D. Quintana, M. L. Bolkovic, M. H. Cassini, and J. I. TúnEz. 2015. The role of river drainages in shaping the genetic structure of capibara populations. Genetica 143:645-656. 
Cardillo, M., A. Purvis, W. Sechrest, J. L. Gittleman, J. Bielby, and G. M. MACE. 2004. Human population density and extinction risk in the world's carnivores. PLoS Biol 2: e197.

Castañeda-Rico, S., L. León-Paniagua, L. A. Ruedas, and E. VázquezDomínguez. 2011. High genetic diversity and extreme differentiation in the two remaining populations of Habromys simulatus. Journal of Mammalogy 92:963-973.

Castañeda-Rico, S., L. León-Paniagua, E. VÁzquez-Domínguez, and A. G. NaVARRo-SigüEnZA. 2013. Evolutionary diversification and speciation in rodents of the Mexican lowlands: The Peromyscus melanophrys species group. Molecular Phylogenetics and Evolution 70:454-463.

Castillo, J. A., C. W. Epps, A. R. Davis, and S. A. Cushman. 2014. Landscape effects on gene flow for climate-sensitive montane species, the American pika. Molecular Ecology 23:843-856.

Ceballos, G., L. Martínez, A. García, E. Espinoza, C. J. Bezaury, and R. Dirzo. 2010. Diversidad, amenazas y regiones prioritarias para la conservación de las selvas secas del Pacífico de México. FCE, Conabio, Conanp. México.

Challenger, A., And J. Soberón. 2008. Los ecosistemas terrestres. Pp. 87-108 in Capital natural de México, Vol. I: Conocimiento actual de la biodiversidad. Conabio. México.

Chambers, J. L., And D. Garant. 2010. Determinants of population genetic structure in Eastern chipmunks (Tamias striatus): the role of landscape barriers and sex-biased dispersal. Journal of Heredity 101:413-422.

Chiappero, M. B., L. V. Sommaro, J. W. Priotto, M. P. Wiernes, A. R. Steinmann, And C. N. Gardenal. 2016. Spatio-temporal genetic structure of the rodent Calomys venustus in linear, fragmented habitats. Journal of Mammalogy 97:424-435.

Combs, M., E. E. Puckett, J. Richardson, D. Mims, And J. Munshi-South. 2018. Spatial population genomics of the brown rat (Rattus norvegicus) in New York City. Molecular Ecology 27:83-98.

Conanp. 2006. Programa de conservación y manejo Reserva de la Biosfera Mapimí, México. Comisión Nacional de Áreas Naturales Protegidas. Secretaría del Medio Ambiente y Recursos Naturales, México.

Cosentino, B. J., R. L. Schooley, B. T. Bestelmeyer, A. J. McCarthy, And K. Sierzega. 2015. Rapid genetic restoration of a keystone species exhibiting delayed demographic response. Molecular Ecology 24:6120-6133.

Creech, T. G., C. W. Epps, R. J. Monello, And J. D. Wehausen. 2014a. Using network theory to prioritize management in a desert bighorn sheep metapopulation. Landscape Ecology 29:605-619.

Creech, T. G., C. W. Epps, R. J. Monello, and J. D. Wehausen. 2014 b. Predicting diet quality and genetic diversity of a desertadapted ungulate with NDVI. Journal of Arid Environments 127:160-170.

Creech, T. G., C. W. Epps, E. L. Landguth, J. D. Wehausen, R. S. Crowhurst, B. Holton, and R. J. Monello. 2017. Simulating the spread of selection-driven genotypes using landscape resistance models for desert bighorn sheep. PLoS ONE 12:e0176960. https://doi.org/10.1371/journal.pone.0176960 Cuervo-Robayo, A. P., O. Téllez-Valdés, M. A. Gómez-Albores, C. S. Venegas-Barrera, J. Manjarres, and E. Martínez-Meyer. 2014. An update of high-resolution monthly climate surfaces for Mexico. International Journal of Climatology 34:2427-2437.

Cullingham, C. I., C. D. Thiessen, A. E. Derocher, P. C. Paquet, J. M. Miller, J. A. Hamilton, and D. W. Coltman. 2016. Population structure and dispersal of wolves in the Canadian Rocky Mountains. Journal of Mammalogy 7:839-851.

Draheim, H. M., J. A. Moore, M-J. Fortin, and K. T. SCribner. 2018. Beyond the snapshot: Landscape genetic analysis of time series data reveal responses of American black bears to landscape change. Evolutionary Applications 11:1219-1230. DYER, R. J. 2015. Is there such a thing as landscape genetics? Molecular Ecology 24:3518-3528.

Epps, C. W., J. D. Wehausen, V. C. Bleich, S. G. Torres, and J. S. BRASHARES. 2007. Optimizing dispersal corridor models using landscape genetics. Journal of Applied Ecology 44:714-724.

Espindola, S., A. D. Cuarón, O. E. GagGiotti, and E. VÁzquez-Domínguez. 2014. High genetic structure of the Cozumel Harvest mice, a critically endangered island endemic: conservation implications. Conservation Genetics 15:1393-1402.

Espinoza-Medinilla, E., I. Sánchez, M. García, and C. LorenzoMonterrubio. 2006. Análisis de la distribución de roedores de la familia Muridae en el sur de México. Pp. 47-54 in Genética y mamíferos mexicanos: presente y futuro (VázquezDomínguez, E. and D. J. Hafner, eds.). New Mexico Museum of Natural History and Science. Albuquerque, U.S.A.

Fernández, J. A., F. A. Cervantes, and M. S. Hafner. 2012. Molecular systematics and biogeography of the Mexican endemic kangaroo rat, Dipodomys phillipsii (Rodentia: Heteromyidae). Journal of Mammalogy 93:560-571.

Flores-Manzanero, A., M. A. Luna-Bárcenas, R. J. Dyer, and E. VázquezDOMínguez. 2019. Functional connectivity and home range inferred at a microgeographic landscape genetics scale in a desert-dwelling rodent. Ecology and Evolution 9:437-453.

Fraser, D. L., K. Ironside, R. K. Wayne, and E. E. Boydston. 2019. Connectivity of mule deer (Odocoileus hemionus) populations in a highly fragmented urban landscape. Landscape Ecology https://doi.org/10.1007/s10980-019-00824-9(0123456789

Frankel, O. H. 1974. Genetic conservation: our evolutionary responsibility. Genetics 78:53-65.

Frankham, R., J. D. Ballou, and D. A. Briscoe. 2010. Introduction to Conservation Genetics, Second edition. Cambridge University Press. New York, U.S.A.

Freeman, S. and J. C. Herron. 2002. Análisis evolutivo. Prentice Hall. España.

Gardner-Santana, L. C., D. E. Norris, C. M. Fornadel, E. R. Hinson, S. L. Klein, AND G. E. Glass. 2009. Commensal ecology, urban landscapes, and their influence on the genetic characteristics of city-dwelling Norway rats (Rattus norvegicus). Molecular Ecology 18:2766-2778.

Garrido-Garduño, T., and E. VÁzquez-Domínguez. 2013. Métodos de análisis genéticos, espaciales y de conectividad en genética del paisaje. Revista Mexicana de Biodiversidad 84:1031-1054.

Garrido-Garduño, T., O. Téllez-Valdés, S. Manel, and E. VázquezDomíngUEZ. 2016. Role of habitat heterogeneity and landscape connectivity in shaping gene flow and spatial population structure of a dominant rodent species in a tropical dry forest. Journal of Zoology 298:293-302.

Gómez-Fernández, M. J., E. S. M. Boston, O. E. GagGiottı, M. J. Kittlein, And P. M. MIROL. 2016. Influence of environmental heterogeneity on the distribution and persistence of a subterranean rodent in a highly unstable landscape. Genetica 144:711-722.

Grünberger, O. 2004. Características esenciales de la Reserva de la Biosfera. Pp. 41-55 in Las playas del desierto chihuahuense 
(parte mexicana): Influencia de las sales en ambiente árido y semiárido (Grünberger, O., V. M. Reyes-Gómez, and J. L. Janeau, eds.). Institut de Recherche pour le Développement. Instituto de Ecología, A. C., México.

Guillot, G., AND F. Rousset, F. 2013. Dismantling the Mantel tests. Methods in Ecology and Evolution 4:336-344.

Guillot, G., R. Leblios, A. Coulon, and A. C. Frantz. 2009. Statistical methods in spatial genetics. Molecular Ecology 18:4734-4756.

Gutiérrez-García, T. A., and E. Vázquez-Domínguez. 2012. Biogeographically dynamic genetic structure bridging two continents in the monotypic Central American rodent Ototylomys phyllotis. Biological Journal of the Linnean Society 107:593-610.

Hall, L. A. And S. R. Beissinger. 2014. A practical toolbox for design and analysis of landscape genetics studies. Landscape Ecology 29:1487-1504.

Hapeman, P., E. K. Latch, J. A. Fike, O. E. Rhodes, and C. W. Kilpatrick .2011. Landscape genetics of fishers (Martes pennanti) in the Northeast: dispersal barriers and historical influences. Journal of Heredity 102:251-259.

He, K. S., B. A. Bradley, A. F. Cord, D. Rocchini, M-N. Tuanmu, S. Schmidtlein, W. Turner, M. Wegmann, and N. Pettorelli. 2015. Will remote sensing shape the next generation of species distribution models? Remote Sensing in Ecology and Conservation 1:4-18.

Hijmans, R. J., S. E. Cameron, J. L. Parra, P. G. Jones, and A. Jarvis. 2005. Very high resolution interpolated climate surfaces for global land areas. International Journal of Climatology 25:1965-1978.

Holderegger, R., and H. H. Wagner. 2006. A brief guide to Landscape Genetics. Landscape Ecology 21:793-796.

Kittlein, M. J., and O. E. GagGiotti. 2008. Interactions between environmental factors can hide isolation by distance patterns: a case study of Ctenomys rionegrensis in Uruguay. Procedings of the Royal Society B 275:2633-2638.

Landguth, E. L., B. C. Fedy, S. J. Oyler-McCance, A. L. Garey, S. L. Emel, M. Mumma, H. H. Wagner, M-J. Fortin, And S. A. Cushman. 2012. Effects of sample size, number of markers, and allelic richness on the detection of spatial genetic pattern. Molecular Ecology Resources 12:276-284.

Laurence, S., M. J. Smith, And A. I. Schulte-Hostedde. 2013. Effects of structural connectivity on fine scale population genetic structure of muskrat, Ondatra zibethicus. Ecology and Evolution 3:3524-3535.

Lefsky, M. A., W. B. Cohen, G. G. PARker, And D. J. Harding. 2002. Lidar remote sensing for ecosystem studies. BioScience 1:19-30.

Legendre, P., AND M-J. Fortin. 2010. Comparison of Mantel test and alternative approaches for detecting complex multivariate relationships in the spatial analysis of genetic data. Molecular Ecology Resources 10:831-844.

Legendre, P., M-J. Fortin, and D. Borcard. 2015. Should the Mantel test be used in spatial analysis? Methods in Ecology and Evolution 6:1239-1247.

Lonsinger, R. C., R. M. Schweizer, J. P. Pollinger, R. K. Wayne, And G. W. Roemer. 2015. Fine-scale genetic structure of the ringtail (Bassariscus astutus) in a Sky Island mountain range. Journal of Mammalogy 96:257-268.

Lopes, C. M., and T. R. O. De Freitas. 2012. Human impact in naturally patched small populations: genetic structure and conservation of the burrowing rodent, tuco-tuco (Ctenomys lami). Journal of Heredity 103:672-681.

LudWig, J. A., B. P. Wilcox, D. D. Breshears, D. J. Tongway, And A. C. IMESON. 2005. Vegetation patches and runoff-erosion as interacting ecohydrological processes in semiarid landscapes. Ecology 86:288-297.

Manel, S., and R. Holderegger. 2013. Ten years of landscape genetics. TRENDS in Ecology and Evolution 28:614-621.

Manel, S., M. K. Schwartz, G. Luikart, and P.TAberlet. 2003. Landscape genetics: combining landscape ecology and population genetics. TRENDS in Ecology and Evolution 4:189-197

Mapelli, F. J., M. S. Mora, P. M. Mirol, and M. J. Kittlein. 2012. Population structure and landscape genetics in the endangered subterranean rodent Ctenomys porteousi. Conservation Genetics 13:165-181.

Marrotte, R. R., A. Gonzalez, and V. Millien. 2014. Landscape resistance and habitat combine to provide an optimal model of genetic structure and connectivity at the range margin of a small mammal. Molecular Ecology 23:3983-3998.

McNeely, J. A., K.R. Miller, W. Reid, R. Mittermeier, and T. B. Werner. 1990. Conserving the World's Biological Diversity. IUCN, World Resources Institute, Conservation International, WWF, and the World Bank. Washington, DC. EE.UU.

McRae, B. H., B. G. Dickson, T. H. KeitT, AND V. B. ShaH. 2008. Using circuit theory to model connectivity in ecology, evolution, and conservation. Ecology 89:2712-2724.

Mittermeier, R. A., P. Robles-Gil, and C. G. Mittermeier. 1997. Megadiversidad: Los países biológicamente más ricos del mundo. Cemex-Agrupación Sierra Madre, México.

Mittermeier, R. A., C. G. Mittermeier, T. M. Brooks, J. D. Pilgrim, W. R. Konstant, G. A. B. da Fonseca, and C. Kormos. 2003. Wilderness and biodiversity conservation. Proceedings of the National Academy of Sciences USA 100:10309-10313.

Montgelard, C., S. Zenboudu, A-L. Ferchaud, V. Arnal, and B. J.Van Vuuren. 2014. Landscape genetics in mammals. Mammalia 78:139-157. Mora, M. S., F. J. Mapelli, A. López, M. J. Gómez Fernández, P. M. Mirol, AND M. J. Kittlein. 2017. Landscape genetics in the subterranean rodent Ctenomys "chasiquensis" associated with highly disturbed habitats from the southeastern Pampas region, Argentina. Genetica 145:575-591.

Moraes, A. M., C. R. Ruiz-Miranda, P. M., Jr. Galetti, B. B. Niebuhr, B. R. Alexandre, R. L. Muylaert, A. D. Grativol, J. W. Ribeiro, A. N. Ferreira, and M. C. Ribeiro. 2018. Landscape resistance influences effective dispersal of endangered golden lion tamarins within the Atlantic Forest. Biological Conservation 224:178-187.

Munguía-Vega, A., R. Rodríguez-Estrella, and M. C. Blázquez. 2007. Characterization of nine microsatellite loci on endemic kangaroo rats Dipodomys simulans peninsularis from southern Baja California Peninsula. Molecular Ecology Notes 7:127-129. MunshI-SOUTH, J. 2012. Urban landscape genetics: canopy cover predicts gene flow between white-footed mouse (Peromyscus leucopus) populations in New York City. Molecular Ecology 21:1360-1378.

Pérez-Consuegra, S. G., and E. Vázquez-Domínguez. 2015. Mitochondrial diversification of the Peromyscus mexicanus species group in Nuclear Central America: biogeographic and taxonomic implications. Journal of Zoological Systematics and Evolutionary Research 53: 300-311. 
Polıs, G. A. 1991. Desert communities: an overview of patterns and processes. Pp. 1-26 in The Ecology of Desert Communities (Polis, G. A., ed.). The University of Arizona Press. Tucson, U.S.A. Ramírez-Pulido, J., N. González-Ruiz, A. L. Gardner, and J. ArroyoCABRALES. 2014. List of recent land mammals from Mexico, 2014. Special Publications, Museum of Texas Tech University 63:1-69.

Reding, D. M., S. A. Cushman, T. E. Gosselink, and W. R. Clark. 2013. Linking movement behavior and fine-scale genetic structure to model landscape connectivity for bobcats (Lynx rufus). Landscape Ecology 28:471-486.

Richardson, J. L., S. P. Brady, I. J. Wang, and S. F. Spear. 2016. Navigating the pitfalls and promise of landscape genetics. Molecular Ecology 25:849-863.

Rıco, Y. 2019. Landscape genetics of Mexican biodiversity: a review. Acta Universitaria 29, e1894. doi. http://doi. org/10.15174/au.2019.1894

Rolland, J., S. Lavergne, and S. Manel. 2015. Combining niche modelling and landscape genetics to study local adaptation: A novel approach illustrated using alpine plants. Perspectives in Plant Ecology, Evolution and Systematics 17:491-499.

Schimel, D. D. 2010. Drylands in the Earth system. Science 327:418-419.

Scribner, K. T., J. A. Blanchong, D. J. Bruggeman, B. K. Epperson, C-Y. Lee, Y-W. Pan, R. I. Shorey, H. H. Prince, S. R. Wintersterin, and D. R. LuUKKonen. 2005. Geographical Genetics: Conceptual Foundations and Empirical Applications of Spatial Genetic Data in Wildlife Management. The Journal of Wildlife Management, 69:1434-1453.

Storfer, A., M. A. Murphy, S. F. Spear, R. Holderegger, and L. P. Waits. 2010. Landscape genetics: where are we now? Molecular Ecology 19:3496-3514.

Storfer, A., M. A. Murphy, J. S. Evans, C. S. Goldberg, S. Robinson, S. F. Spear, R. Dezzani, E. Delmelle, L. Vierling, and L. P. Waits. 2007. Putting the "landscape" in landscape genetics. Heredity 98:128-142.

Téllez-Valdés, O., V. Farías, P. Dávila, J. L. Stein, R. Lira, and F. J. Botello. 2010. Mammalian diversity in climatic domains for Tehuacán-Cuicatlán Biosphere Reserve, Mexico. Revista Mexicana de Biodiversidad 81:863-874.

ThimmaYYA, A. C., AND S. W. BuskIRK. 2012. Genetic connectivity and diversity of pygmy rabbits (Brachylagus idahoensis) in southern Wyoming. Journal of Mammalogy 93:29-37.

TURner, M. G. 2005. Landscape Ecology: What is the state of the science? Annual Review of Ecology, Evolution, and Systematics 36:319-344.

Vázquez-Domínguez, E., and R. Vega. 2006. ¿Dónde estamos y hacia dónde vamos en el conocimiento genético de los mamíferos mexicanos? Pp. 67-73 in Genética y mamíferos mexicanos: presente y futuro (Vázquez-Domínguez, E., and D. J. Hafner, eds.). New Mexico Museum of Natural History and Science. Albuquerque, U.S.A.

VÁzqueZ-DomíngueZ, E., AND S. EspindolA. 2013. Characterization of ten new microsatellite loci from the endangered endemic rodent, Reithrodontomys spectabilis. Conservation Genetics Resources 5:251-253.

Vega, R., E. Vázquez-Domínguez, A. Mejía-Puente, and A. D. Cuarón. 2007. Unexpected high levels of genetic variability and the population structure of an island endemic rodent (Oryzomys couesi cozumelae). Biological Conservation 37:210-222.
VIGNIERI, S. N. 2005. Streams over mountains: influence of riparian connectivity on gene flow in the Pacific jumping mouse (Zapus trinotatus). Molecular Ecology 14:1925-1937.

Waits, L. P., S. A. Cushman, And S. F. Spear. 2015. Applications of landscape genetics to connectivity research in terrestrial animals. Pp. 199-219 in Landscape Genetics: Concepts, Methods, Applications (Balkenhol, N., S. A. Cushman, A. T. Storfer, and L. P. Waits, eds.). John Wiley \& Sons, Ltd. The Atrium, Chichester, U.K.

Walker, R. S., A. J. Novaro, and L. C. Branch. 2007. Functional connectivity defined through cost-distance and genetic analyses: a case study for the rock-dwelling mountain vizcacha (Lagidium viscacia) in Patagonia, Argentina. Landscape Ecology 22:1303-1314.

Whitford, W. 2002. Ecology of Desert Systems. Academic Press, an Elsevier Science Imprint. San Diego, California. U.S.A.

Wilson, D. E., R. A. Mittermeier and T. E. Lacher. 2017. Handbook of the Mammals of the World, Vol 7: Rodents II. Lynx Editions. Barcelona, España.

Wultsch, C., A. Caragiulo, I. Dias-Freedman, H. Quigley, S. Rabinowitz, AND G. AmATo. 2016. Genetic Diversity and Population Structure of Mesoamerican Jaguars (Panthera onca): Implications for Conservation and Management. PLoS ONE 11:e0162377. doi:10.1371/journal.pone.0162377

WWF (WoRLd WiLdLIFE FUND). 2019. Deserts and xeric shrublands. Recuperado de https://www.worldwildlife.org/biomes/ deserts-and-xeric-shrublands el 21 de mayo de 2019.

ZENG, N., AND J. YoON. 2009. Expansion of the world's deserts due to vegetation-albedo feedback under global warming. Geophysical Research Letters 36:17-20.

Associated editor: Monica Díaz

Submitted: June 3, 2019; Reviewed: July 3, 2019;

Accepted:July 27, 2019; Published on line:September 20, 2019. 
394 THERYA Vol. 10 (3): 381-393 